\title{
RUSSIAN ARCTIC SECTOR BOUNDARIES: THE INTERNATIONAL ISSUES OF LEGAL REGIME IN THE ARCTIC REGION
}

\author{
Sofiya Shvelidze \\ IMO International Mariitme Law Institute, Msida, Malta, info@imli.org
}

\begin{abstract}
Research purpose. The regime of maritime spaces as a general rule 'is determined by the principles and norms of international law relating to the oceans and enshrined in the Geneva Convention on the Law of the Sea of 1958 and the United Nations Convention on the Law of the Sea of 1982(UNCLOS). However, the issue is that UNCLOS practically does not fix any special regime on the Arctic, bearing in mind that the use of the Arctic spaces is rather effectively regulated at the national levels. Arctic issues in this regard lacked in-depth analysis, and no attempts to develop specific norms and approaches with regard to the Arctic region were made, with the exception of Article 234 of UNCLOS, which is related to the right of the coastal States to 'regulate navigation' in its Exclusive Economic Zones. The purpose of the current research is to analyse how far a State may go in the process of establishment of the laws and regulations while exercising the right granted by Article 234, with the particular focus made on the position taken by the Russian Federation.

Design / Methodology / Approach. In order to achieve the aims of the research, a descriptive method was chosen as the method for clarification on the legal regime currently applicable in the Russian Arctic Sector, in particular supported by the dogmatic method, in order to understand and explain the position taken by the legislative bodies.

Findings. The result of the research is the attempts to satisfy how having interests and stakes in the region of high overall salience contributes to prioritization by Russian Federation of its rights over the region by restrictions imposed on the navigational freedoms granted to the States by UNCLOS. Additionally, suggestions are made in respect of the possible solutions necessary in order to strike a balance between national interests of the Arctic States and rights of others States to access the area without causing any harm to the environment and security of the region.
\end{abstract}

Keywords: Environment in iced-cover areas; Legal regime; Russian Arctic Sector; UNCLOS.

JEL codes: K32; K33; K39.

\section{Introduction}

In the fundamentals of the State Policy of the Russian Federation in the Arctic region for the period up to 2020 and beyond, approved by the President of the Russian Federation on 18 September 2008, a significant political, economic and legal term was introduced - the Arctic zone of the Russian Federation. In this regard, a number of substantive legal issues arose: the meaning of this term; its relation to the terms previously used in legal doctrine, including 'the USSR polar possessions sector', 'Russian Arctic'; what are the legal boundaries of the Arctic zone of the Russian Federation; what is the legal regime of this space, specifically, the legal regime of the economic activity and environmental protection.

At the same time, a number of foreign studies consider that the legal regime of the Arctic is rapidly changing as the areas in the Arctic Ocean covered with centuries-old ice constantly shrink. Influential construct models of the Arctic policy are building regional scenarios for the evolution of the legal regime of this region, determining the potential impact of such an evolution on all spheres of States' life including society and business. Within the framework of strategic forecasting of the consequences of potential 'global' Arctic policy, projects are being initiated, the purpose of which is to provide a theoretical description of favourable political and legal conditions in order to meet the interests of a particular foreign State or regional interstate association.

Representatives of the natural sciences do not question the importance of the Arctic region for the formation of the Earth's climate, especially the temperature macro dynamics of the planet. For the Russian Federation, due to its geographical location, bearing in mind the fact that many of its regions 
are located in high latitudes of the Northern Hemisphere, it is necessary to take into account everything that happens in the Arctic. Special importance is given to the ambiguous predictions of changes in the legal regime of the Arctic region, as well as the fact that this polar region has now grown substantially and now is also being considered by many other countries in the world, in particular, the economically developing Asian states, including People's Republic of China.

In addition, due to the depletion of the natural resource base of the land part of our planet, the promising value of the seabed and subsoil of the Arctic Ocean increases, and this factor in the modern conditions of the economic interdependence of the world and global warming aggravates the problems of interstate competition and rivalry in the development of Arctic spaces and their natural resources. The Arctic States (Russia, United States, Canada, Denmark, Iceland, Norway, Finland and Sweden) consistently confirm their fundamental interests in the Arctic. On the other hand, there are a number of 'newcomers' in the Arctic region such as Germany, China, Japan, Austria, Great Britain and Republic of Korea, as well as the European Union.

The international agreements that are applicable to the definition of the legal status of the Arctic zone of the Russian Federation are chosen as the base for the research: first of all, The St. Petersburg Convention regarding the delimitation of mutual spaces of possessions of Russia and Great Britain in North America in 1825, the Convention on the assignment to the United States of the Russian North American Colonies (Convention on the Assignment of Alaska) 1867, the 1982 UN Convention on the Law of the Sea, Convention on Biological Diversity of 1992, Convention on the Continental Shelf of 1958, Agreement on the Conservation of Polar Bears of 1973, Agreement on Cooperation in Aeronautical and Maritime Search and Rescue on the Arctic, 2011; second, relevant acts of legislation of the Russian Empire, USSR, Russian Federation: Decree of the Governing Senate of 1821, Decree of the Council of People's Commissars of the RSFSR of 1921 'On the protection of fish and animal lands in the Arctic Ocean and the White Sea', Resolution of the Presidium of the USSR Central Election Commission dated 15 April 1926 'On declaring lands and islands located in the Arctic Ocean as the territory of the USSR', USSR Law from 1984 'On approving the Decree of the Presidium of the Supreme Soviet of the USSR "On enhancing nature conservation in the Far North and areas adjacent to the northern coast of the USSR"', Resolution of the Council of Ministers of the USSR in 1990 'On measures to ensure the implementation of the Decree of the Presidium of the Supreme Soviet of the USSR of November 26, 1984 "On strengthening environmental protection in the Far North and marine areas adjacent to the northern coast of USSR"', Rules of navigation on the routes of the Northern Sea Route in 1990, and so on; as well as political and legal documents of the directive level: Fundamentals of the state policy of the Russian Federation in the Arctic for the period up to 2020 and beyond, Maritime Doctrine of the Russian Federation for the period up to 2020.

The purpose of the work is to identify the content of the legal regime of the Arctic zone of the Russian Federation as a modern large-scale object of international law, in analytical and legal comparison of this concept with those previously designated by the domestic jurisprudence ('polar sector of the USSR', 'Russian Arctic') and also in the designation of a scientific approach to the determination of the spatial limits of the Arctic zone of the Russian Federation.

In order to achieve this goal, it is important to perform the following tasks: compare the existing definitions of the terms 'Arctic', 'Russian Arctic', 'Arctic zone of the Russian Federation'; outline the historical and legal context of their formation, as well as their legal meaning; identify the substantive components of the legal regime of the Arctic zone of the Russian Federation; determine the scientific and legal approach to the designation of the spatial limits of the Arctic zone of the Russian Federation, its southern, eastern, northern and western borders; identify the international legal peculiarities of the Arctic zone of the Russian Federation; analyse international legal norms applicable to environmental protection in the Arctic zone of the Russian Federation, its economic activities, scientific research and the use of living resources in its high-latitude regions.

\section{Literature Review}

The delimitation of the Arctic region by the national sectors of the Arctic States up to the beginning of the 21 st century has not been disputed by other states; however, in the last decade, the trend of non- 
Arctic States and a number of associations (EU, NATO) towards the formation of a new global legal regime of the Arctic zone has been clearly observed. In this regard, the current understanding of the doctrines of national sectors is ambiguous. Even in the domestic doctrine, there is no single approach to this position. Sivakov believes that 'the doctrine of the national sectors is somehow firmly justified only in relation to land - islands and archipelagos' (Sivakov, 2012); that is, in relation to the maritime spaces of the Arctic, according to the scientist, there is already another regulation - the one based on the UNCLOS's provisions.

A number of scientists recognize that the legal regime of the Arctic, based on the sectorial principle of demarcation of the spheres of action of the sovereignties of the polar states, is a common norm of international law. Guslitcer recognizes the customary legal nature of these norms and also notes that the Arctic seas 'are special flood-type seas, such as historical bays. The development of these seas (the Kara Sea, the Laptev Sea, the East Siberian Sea, the Chukchi Sea) is a historical merit of the Soviet state' (Guslitcer, 1954).

Zhudro also takes the position that, with regard to sectorial division of the Arctic space, one should speak about the presence of established international legal customs. International legal customs in the Arctic are long-term law-enforcement practices of the Arctic States themselves, having been recognized by other countries. By virtue of international legal customs, only five coastal States exercise sovereignty over internal sea waters, territorial sea, their seabed and subsoil, as well as special rights in their " polar possessions"” (Zhudro, 2014).

A.N. Vylegzhanin agrees with the customary legal regime of the legal regulation in the Arctic (Vylegzhanin, 2009).

Nowadays, the concept of sectorial division of the Arctic space is being criticized, primarily by nonArctic States. Therefore, giving the sectorial principle, the status of a custom, that is, a norm 'established on the basis of a long recognition', loses its relevance (Philimonov, 2015). It is important to understand in this regard how the Arctic powers cooperate on the issue.

One needs to also pay attention to the Ilulissat Declaration of 2008, adopted in the city of Ilulissat (Greenland) by the Arctic States, which reinforced the following intentions of the participating States: "By virtue of its sovereignty, sovereign rights and jurisdiction over significant areas of the Arctic Ocean, five coastal States are in a unique position to respond to these opportunities and challenges. In this context, we recall that with regard to the Arctic Ocean, an extensive international legal framework is being applied, as noted by our representatives at the level of senior officials at the meeting in Oslo from 15 to 16 October 2007. In particular, the law of the sea enshrines important rights and obligations relating to the definition of the outer limits of the continental shelf, the protection of the marine environment, including ice-covered areas, freedom of navigation, marine scientific research and other uses of the sea. We remain committed to this legal framework and to a peaceful settlement of any possible overlapping claims".

Thus, the representatives of Russia, Canada, Norway, Denmark and the United States stated that there is no need to create a new universal international legal regime for the Arctic Ocean (Avkhadeev, 2016). That is, in fact, the stakeholders had expressed their rejection of the idea with respect to the revision of the legal regulation of the regime of the Arctic space.

It seems that, despite the consolidation of the stated intentions of the Sstates, disputes related to the delimitation of maritime spaces in the Arctic zone still exist. At the same time, one cannot underestimate the significance of this declaration, which, although is only of advisory nature, reflects the commitment of the Arctic States to cooperate and commit themselves to the protection of the Arctic space, as well as to consolidate a certain status quo with respect to the legal regime of the Arctic Ice. Such a joint statement of the subarctic States is especially important given the fact that, in the world community, there is a tendency from non-strategic states towards the establishment of a new regime for the Arctic space, in particular, recognition of the Arctic as a free region open to the activities of all states, what goes contrary to the interests of the subarctic States.

In addition, P. Gudev notes the advantages of customary law, drawing attention to the fact that "customary law norms cannot be regarded as subordinates with respect to conventional treaty norms. 
The international customary law fulfils a certain general-purpose role - it expresses the imperatives of behaviour more effectively and is the initial basis of the international legal order, and establishes the criteria that the norms of a contractual nature must meet." The undoubted merit of customary law is the extension of these rules to all subjects of international law, whereasile the norms of international treaties are binding only for the parties to such treaties (Gudev, 2016).

However, for the state practice to acquire international status and become the legal regulator of international legal relations with respect to the Arctic, it is necessary that these provisions be recognized or unchallenged by all members of the international community. Bearing it in mind, the characteristic of the customary rule is now in doubt.

Proponents of the position that the Arctic is a maritime space, not endowed with a special status and legal regulation, believe that the legal regulation of the Arctic Ocean is carried out in accordance with the UNCLOS. Avhadeev draws attention to the fact that, in the Arctic region, the sovereignty of states is particularly vulnerable to the maritime spaces, to which the legal regime in accordance with international maritime law applies (Avhadeev, 2016). Lukin is convinced that the UNCLOS has changed the geo-political situation in the Arctic: 'The national interests of each subarctic State can now be realized on the basis of the already completely legitimate basis of international law' (Lukin,2011).

Thus, the UNCLOS allows each Arctic State to establish the breadth of its territorial sea to a limit not exceeding 12 nautical miles, measured from baselines (Article 3 of the Convention). With respect to the territorial sea, the coastal state is granted a whole range of sovereign rights. The coastal state has the right to adopt laws and regulations that regulate the issues of innocent passage through the territorial sea; shipping safety and traffic control; the protection of navigational aids and equipment, as well as other structures or installations; conservation of living resources of the sea; preservation of the environment of the coastal state; as well as other issues established in Article 21 of the Convention. Foreign ships exercising the right of innocent passage, the concept of which is given in Articles 18 and 19 of the Convention, are required to comply with laws and regulations established by the coastal State. By virtue of Article 22 of the Convention, the coastal state has the right to demand from foreign vessels exercising the right of innocent passage to use sea corridors and traffic separation schemes established by the coastal State. The Convention also establishes the rights of protection of the coastal State in the event of a security risk (Article 25 of the Convention), rules of criminal jurisdiction on board a foreign ship (Article 27 of the Convention) and rules of civil jurisdiction regarding foreign ships (Article 28 of the Convention)).

Part V of the Convention also establishes for coastal States an exclusive economic zone, the breadth of which shall not exceed 200 nautical miles, measured from baselines, from which the breadth of the territorial sea is measured (Article 57 of the Convention). In this exclusive economic zone, the coastal state exercises sovereign rights to explore, exploit and preserve living and non-living resources, as well as managing resources in the waters covering the seabed, on the seabed and in its subsoil, as well as for managing these resources, economic intelligence activities and the development of this zone. Coastal States also exercise jurisdiction over the creation and use of artificial islands, installations and structures; marine scientific research; protection and preservation of the marine environment (Article 56 of the Convention). At the same time, in the exclusive economic zone, the coastal state due to the part 2 of Article 56 of the Convention is forced to take into account the rights and obligations of other states in the exclusive economic zone (freedom of navigation and over flight, the possibility of laying of submarine cables and pipelines by these states and other legitimate uses of the sea in accordance with international law).

In accordance with paragraph 1 of Article 76 of the Convention, the continental shelf of a coastal state includes the seabed and subsoil of submarine areas extending beyond its territorial sea throughout the natural prolongation of its land mass to the outer limit of the continental submerged margin or 200 nautical miles from the baselines, from which the breadth of the territorial sea is measured, when the outer limit of the continental margin does not extend to such a distance.

In accordance with paragraph 8 of Article 76 of the Convention, data on the limits of the continental shelf beyond 200 nautical miles from the baselines, from which the breadth of the territorial sea is measured, are to be submitted by the respective coastal State to the Commission on the Limits of the 
Continental Shelf. In this case, the coastal State in accordance with Article 77 of the Convention exercises exclusive sovereign rights in the exploration of the continental shelf and the exploitation of its natural resources. The essence of these exclusive rights is also that if a coastal State does not research the continental shelf or exploit its natural resources, no other state can do so without the express consent of the coastal State.

The essence of such regulation is that the seabed and resources that are outside of the continental shelf of a coastal State are recognized as the common heritage of humankind, that is, no state has the right to make claims with regard to sovereign rights in relation to such maritime space.

However, not all scientists agree that the conventional regulation applies to the Arctic space. Avhadeev believes that only Article 234 of the Convention relates to 'Ice-covered Areas', which enshrines the right of states to adopt and enforce non-discriminatory laws and regulations for the prevention, reduction and preservation of marine pollution from ships in ice-covered areas within the exclusive economic zones (Avhadeev, 2016), whereas other legal aspects of regulating the regime of the polar regions under the UNCLOS are not regulated. On the other hand, Cinelli rightly draws attention that the presence of Article 234, or the so-called Arctic clause, is an exception, which only confirms the general rule that the Arctic marine spaces are considered as any other marine spaces (Cinelli, 2011).

According to Tiunov, the principles for defining the limits of the continental shelf, formulated in the Convention, do not apply to the Arctic region. Application of the provisions of Art. 76 of the 1982 Convention relating to the multi-variant consideration of geological factors in determining the boundaries between the continental shelf of the Arctic state and the international seabed area cannot take place due to the fact that there is no evidence of agreement of the Arctic States Parties to the Convention 1982 for the creation in the Arctic of such an area, which would mean the regime of the 'common heritage of humankind' (Tiunov, 2009).

Zhudro is convinced that the significance of universal norms of the Convention is exaggerated, whereas the role of international customs is underestimated. In the Arctic, all global mechanisms created by the 1982 Convention and, above all, in such a sensitive issue today, do not work just the for the purposes of the distinction between the underwater spaces (continental shelf) of the Arctic Ocean. First of all, due to the huge differences between the ice-covered regions of the North and the warm waters of the Indian Ocean (the 1982 UN Convention did not specifically mention the polar regions - the Arctic and Antarctic - they were not the subject of the III conference on the law of the sea 1973-1982) (Zhudro, 2014).

Nikolaev and Peshchurov believe that the legal status of the Arctic region is unique; the Arctic cannot be viewed as a whitespace object of law - 'the role of the Arctic states in creating legal norms, their implementation and enforcement is decisive' (Nikolaev \&Peshchurov, 2012).

Also, as an argument for the non-applicability of the Convention to Arctic, Efendiyev and Zhudro consider non-participation in the 1982 Convention of one of the Arctic States - the United States - and its failure to comply with the Convention provisions on the self-limitation of the continental shelf in favour of the seabed area (Zhudro, 2014).

Opponents of the Conventional Regulation of the Arctic believe that at the present time there is already a sufficiently developed mechanism of legal regulation of the Arctic space, consisting of the international customs. Zhudro considers the current legal regime of the Arctic Ocean as sufficient for the peaceful settlement of disputes - there is no need to create a new common governance of this region. In support of his position, the scholar cites the practice of the United Nations International Court of Justice, which, in assessing the boundaries of the continental shelf, is guided by the rules of customary law as a priority over conventional ones; for example, the principle of natural continuation is the rule that the coastal state's rights with respect to the continental shelf, which is the natural prolongation of its land territory in and under the sea, and exists ipso facto and ab initio, owing to its sovereignty over this territory, and not due to rules stated in the UNCLOS (Zudro, 2014).

Tiunov insists on regulation of the Arctic space by the Arctic powers. The Arctic States, as having primary responsibility for the preservation of the Arctic ecosystem, could develop a mechanism for implementing this responsibility not on the basis of the Convention, but on the basis of international 
customary law. Part of the solution to this issue should be the distinction between the neighbouring states of the Arctic shelf in accordance with general international law (Tiunov, 2009).

Avhadeev proposes the delimitation of maritime spaces in the waters of the Arctic Ocean, taking into account the principles of the sovereign equality of states, as well as the principle of inviolability of the territory: 'It is paramount that when resolving issues of jurisdiction of each particular Arctic State with respect to certain spaces of the Arctic, neither the sovereign rights of the arctic State, nor the integrity of its state territory are affected' (Avhadeev, 2016).

Thus, the majority of domestic scientists point out that the legal status of the Arctic is sufficiently settled by the usual legal norms; therefore, the status of the Arctic is unique and is not subject to regulation under the Convention. The arguments of these scientists are supported by the intentions of the Arctic States, formulated in the Ilulissat Declaration.

Taking into account the reasoned arguments of supporters of the sectorial regulation of the Arctic space as a historically established customary norm of international law, it is necessary to state the fact that legal regulation does not stand still. Considering that a customary norm of international law is an obligatory rule of conduct for which the subjects of international law recognize legal obligation, that is, a customary rule exists only if such a rule is recognized by subjects of international law, it should be noted that currently, the sectorial principle may lose the characteristics of the generally accepted norm due to the changing approaches of other Arctic and non-Arctic powers with the specified division.

In this respect, Vylegzhanin rightly draws attention to the fact that 'the realities of the modern Arctic do not mean at all the inviolability of the established legal status of the Arctic Ocean', since progressive development is inherent in international law (Vylegzhanin, 2013).

\section{Methodology}

For the purposes of the research, an interdisciplinary character of methodology was achieved through the theoretical approach taken, combining various disciplinary-based sources namely political science, legal perspective and international relations for better understanding of the relevant problems and identification of the possible solutions. A comparative legal method is also applied with regard to the national and international regulations applicable within the Arctic region. Taking into consideration the purpose of the research, which is, primarily, the development of the knowledge on the subject matter, an epistemological approach was adopted in order to combine indeed practical aspects.

The first thing to do is to gather the relevant literature and other types of the doctrinal sources that are available with respect to the subject matter. Such sources exist in the form of books, scholars' monographs and journal articles, which are taken from reliable international scientific journals. Additionally, relevant domestic and international legislative instruments are considered including inter alia international conventions and agreements, documents of the relevant international organizations and bodies. However, non-academic or informal resources, for example, various informal reports and documents provided by the parties, also support research. The materials in question are collected from both material and web sources. Literature review creates the preliminary foundation for the research.

\section{Results}

The sustainable development of the Arctic space is ensured through joint efforts of the Arctic States together with the establishment of the specific domestic regulations of these powers. In this regard, the analysis of the current legislative instruments of Russian Federation concerning its Arctic area was of crucial importance. Konovalov stated that 'the Arctic area of the Russian Federation cannot exist separately from the world and the country itself, it is built into the system of both global international and Russian processes' (Konovalov, 2011). Indeed, the national policy, and the regulatory framework related to the development of the Arctic region accordingly, cannot remove from its considerations the international legal situation in the region, as well as the relationship with other Arctic States. It is also necessary to take into account the unequal level of the leading powers with respect to the level of technological development, which provides the opportunities for the exploration and exploitation of the Arctic resources and should also be reflected in the domestic policy of the Russian Federation. 
Currently, there is no consensus in legal doctrine and practice with respect to the legal status of the Arctic space. The approaches taken in determination of the definition of the region together with its legal status are radically opposite. One approach is to consider the Arctic to be divided between the Arctic States according to the sectorial principle. Another position taken is to entitle the region with the special status due to the presence of specific geographical, geomorphological and climatic features combination. The third approach is to consider the Arctic as a marine space with the status of 'the common heritage of mankind', which is covered by the norms of international law, in particular, the provisions of the 1982 United Nations Convention on the Law of the Sea. The historically wellestablished principle of sectorial division of the Arctic region is currently undergoing a review by a number of States and International Unions hampering its position to be considered as one of the norms of customary international law. Taking such circumstances into consideration, there is a possibility for the establishment of the new global regime for the purposes of Arctic's management, according to which the area will be regarded as the common heritage of mankind. Such position not only contradicts the strategic and economic interests of the Russian Federation, but also poses a threat to the national and environmental security of all subarctic States.

The abandonment of the sectorial type of division in the Arctic will lead to the loss of sovereign rights of Russian Federation over 1.7 million $\mathrm{km}^{2}$, and such loss by no means may be reimbursed by the extension of the outer limit of continental shelf (Kovalev, 2009). Furthermore, such delimitation procedure will not resolve any issue regarding the delimitation of the continental shelf between the subarctic States, but only affect the international seabed area, which is recognised by the international community as the common heritage of mankind, what contradicts with the national interests of the Russian Federation. However, despite the criticism of the application to the Commission on Delimitation of the Continental Shelf on the delineation of the outer limits of the continental shelf of the Russian Federation, the decision to submit such application is legally and politically approved with the aim to establish a sustainable implementation of its sovereign rights in the Arctic space.

In 2016, the Ministry of Economic Development of the Russian Federation developed a draft of the federal law 'On the development of the Arctic zone of the Russian Federation', which has now passed the stage of public discussion. In accordance with this project, Arctic zone is allocated as a special object of the government and is not part of the administrative-territorial division of the Russian Federation (part 4, Article 1 of the draft). The concept of 'supporting development zone in the Arctic' was introduced, which is a comprehensive project for planning and ensuring the socio-economic development of the Arctic zone, aimed at achieving strategic interests and ensuring national security in the Arctic, providing for synchronous interconnected use of existing instruments of territorial and sectorial development and mechanisms for the implementation of investment projects, including those based on the principles of public-private partnership.

The project regulates the order of creation, development, financing of projects related to the support zone, the procedure for the construction in such zone. The project also sets the basis for the State regulation in the Arctic area of the Russian Federation in the field of environmental management, environmental protection and environmental activities (Article 20); scientific, technical and innovative activities (Article 21); and social development (Articles 22-24). In general, the Draft Project is a framework regulation setting up the basis for the implementation of regulation in the development of the Arctic region, including environmental management, environmental activities and social development. In any case, the effectiveness of regulation of the Arctic region will depend on how the by-law regulation will be carried out by authorized state bodies.

Nowadays, the directions of the development in the Arctic area of the Russian Federation are indicated in such documents as the Foundations of the State Policy of the Russian Federation in the Arctic for the period up to 2020 and beyond, and the Strategy for the Development of the Arctic Zone of the Russian Federation and Ensuring National Security for the Period to 2020 - Development Strategy of the Russian Arctic. Thus, the Development Strategy of the Russian Arctic demonstrates the current state of the socioeconomic development of the Arctic area of the Russian Federation, reflects the key risks and threats in the social sphere, the economic sphere, science and technology, in the field of environmental management and environmental protection. Paragraph 7 of the strategy defines priority areas for the development of the Arctic zone of Russia as follows: 
a) a comprehensive socio-economic development of the Arctic area of the Russian Federation; b) the development of science and technology; c) the creation of a modern information and telecommunications infrastructure; d) ensuring environmental safety; e) international cooperation in the Arctic; (e) ensuring military security, protection and security of the state border of the Russian Federation in the Arctic.

Paragraph 12 of the Strategy identifies measures aimed for the development of the transportation system infrastructure of the Arctic, ensuring 'the preservation of the Northern Sea Route as one of the national transport highway of the Russian Federation'. Legal regulation of the Northern Sea Route is carried out in the Merchant Shipping Code of the Russian Federation and the Rules of Navigation in the waters of the Northern Sea Route, approved by the Order No. 7 of 17 January 2013 of the Ministry of Transport of Russia. The administration of the Northern Sea Route deals with the organization of navigation of vessels in the waters of the Northern Sea Route.

In general, it should be noted that domestic legislation needs to be developed and improved, since at present the regulatory acts of the Arctic zone of Russia are obviously not enough. Moreover, the Arctic zone has specific climatic, environmental, socio-economic conditions, the presence of indigenous peoples and nations, which should be reflected at the level of legislation and subordinate regulatory legal acts. It is also important to increase the investment attractiveness of the region in order to implement large-scale projects, and for this, 'due to high labour intensity and capital intensity, significant payback periods, a long time period from the start of investment to profit, a preferential tax regime, flexible tariff, customs, credit, budget and insurance policies' need to be adopted.

\section{Conclusions}

In the context of the growing trend of the 1982 United Nations Convention on the Law of the Sea applicability to the Arctic and recognition of the region as open sea rather than as marine spaces of the Arctic Ocean as it was under the sectorial principle together with the consideration of the seabed as an international area, it is of utmost importance for the Russian Federation to continue the usage of the existing contractual international legal mechanisms in order to establish the outer limit of continental shelf and thereby create a legal certainty in the spaces mentioned. In the meantime, it is also important to have an agreement on the delimitation of the continental shelf with the other subarctic States namely Canada and Denmark, because the boundaries of the continental shelf with these countries may coincide in the process of delineation, which fact may be seen upon considering the submissions to the commission made by these States. In this regard, attention should be paid to the positive role of the existing agreement between the USSR and the United States concluded in 1990 as well as the treaty between the Russian Federation and Norway of 2010. Even though these treaties were the results of long negotiations, compromises and concessions, the certainty achieved through the conclusion of such agreements with respect to the delimitation of the maritime borders contributes to the sustainable regulation in the field of jurisdiction in the Arctic.

With respect to the position currently taken in the Northern Sea Route of the Russian Federation, it is advisable to unite efforts with Canada, who is interested in consolidating its rights over the Northwest Passage, in order to form a unified legal position as against the approach taken by the United States (recognising both transport routes as international straits for navigation purposes). The Northern Sea Route, taking into consideration all the specific features of the region including navigational, security and environmental factors, should be seen as a single transport communication route. Such position implies the Russian Federation, due to the complex historical, geographical and environmental factors, should have exclusive rights with respect to the establishment of the regime for passage through the Northern Sea Route, navigation standards and environmental supervision. In this regard, the domestic legislation of the Russian Federation needs also to be further developed and improved because it lacks regulation of the substantial amount of issues in the Arctic area, even though the region has significant climatic, economic and social features for the whole State. The adoption of a comprehensive federal law on the Arctic sector of the Russian Federation may serve as the foundation for further concretization of the legal regulation of the issues arising in the Arctic part of the Russian Federation, both at the specific legislation instruments and in the subsequent by-laws. 


\section{References}

Agreement on Cooperation on Aeronautical and Maritime Search and Rescue in the Arctic, 2011. Available from Internet: http://hdl.handle.net/11374/531.

Avhadeev V. (2016) Multilateral international treaties, regulating the legal regime of the Arctic. Journal of Russian State Law, (2), 135-143.

Basics of the state policy of the Russian Federation for the Arctic to 2020 and beyond, 2009. Available from Internet: http://www.arctis-search.com/Russian+Federation+Policy+for+the+Arctic+to+2020.

Cinelli,C.(2011) The Law of the Sea and the Arctic Ocean. Arctic Review on Law and Politics, (2), 4-24.

Convention on the Continental Shelf, 1958. Available from Internet: http://legal.un.org/ilc/texts/instruments/english/conventions/8_1_1958_continental_shelf.pdf

Efendiev O. (1974) Arctic Waters. Modern international maritime law. The regime of the waters and seabed of the World Ocean, (1),184-190.

Fillimonov, U. (2015) International legal and national status of the Arctic. Gaudeamus Igitur. (2), 39-42.

Gudev, P. (2016) Arctic as the "Global Commons"?. Routes towards peace and security, (50), 53-69.

Guslitcer, G. (1954) International Legal Regime of the Arctic and Antarctic regions. Autoreferat of the dissertation work of the PhD candidate. Moscow, 15.

Konovalov, A. (2011) Arctic: national interests in the conditions of globalisation. Strategy for the economy development, (48), 20-28.

Kovalev, A. (2009) International legal regime of the Arctic and interest of the Russia. Security index.(3-4), 115124.

Lukin, U. (2011). The treaty between Russia and Norway - step towards the peaceful delimitation of the maritime space of Arctic. Arctic and the North, (2), 1-29.

Nikolaev, A. Pechurov, S.(2012) Legal opportunities for the Russia to prevent the loss of the part of its continental shelf in the Arctic region. Moscow journal of International Law,(2) 5-29.

Northern Sea Route Handbook. The Japan Association of Maritime Safety, (2015). Available from Internet: http://www.nikkaibo.or.jp/pdf/NorthernSeaRouteHandbook_E.pdf.

Oleniceff, S. (1972) Territorial Waters in the Arctic: The Soviet Position. California: Advanced research projects agency. [Accessed 20/01/209]. Available from https://www.rand.org/content/dam/rand/pubs/reports/2009/R907.pdf.

Resolution of the Presidium of the USSR Central Election Commission dated April 15, 1926 "On declaring lands and islands located in the Arctic Ocean as the territory of the USSR".

Sivakov, D. (2010) Principal approaches towards the Arctic Regulation. Vestnik Povoljskogo instituta upravlenia, (4), 106-110.

The St. Petersburg Convention regarding the delimitation of mutual spaces of possessions of Russia and England in North America in 1825, (Anglo-Russian Convention of 1825). Available from Internet: http://explorenorth.com/library/history/bl-ruseng1825.htm.

Tiunov, O.(2009) The impact of the international conventions and customs on the national law. Vestnik Rossiiskogo gosudarsvennogo gumanitarnogo universiteta, (11), 269-285.

United Nations Convention on the Law of the Sea, 1982. Available from Internet: https://www.un.org/Depts/los/convention_agreements/texts/unclos/UNCLOS-TOC.htm

Vilegzhanin, A.(2013) Legal position of the Arctic Region in the documents. Arctic region: the problems of the international cooperation. Moscow: Aspect-press, 11-44.

Vilegzhanin, A.(2009) Legal regime of the Arctic. International Law. (2), 39-42.

Zhudro, I. (2014) Norm-regulating rules as the component of the unique, historically developed status of the Arctic. Vestnik Severnogo (Arkticheskogo) federalnogo universiteta. Seriya Gumanitarnie i socialnie nauki, (6), 110-118. 